\title{
Female adolescents and the use of contraceptives in rural areas
}

\section{Remaja perempuan dan penggunaan alat kontrasepsi di pedesaan}

\author{
Nuzzulil Nur Abdilla ${ }^{\bowtie}$ Sutinah \\ Department of Sociology, Faculty of Social and Political Sciences, Universitas Airlangga \\ Surabaya, 60286, East Java, Indonesia \\ E-mail of corresponding author: nuzzuli111@gmail.com
}

\begin{abstract}
Contraception is an effort used to prevent pregnancy in women of childbearing age. Presently, contraception is not only used for adult women or those who have had a partner, but also for female adolescents. This study aimed to understand the practice of using contraceptives among female adolescents in rural areas. The theory used as an analytical tool was the theory of social construction by Peter L Berger and Thomas Luckmann. This study used a qualitative method. The research subjects in this study were women who used contraceptives as an adolescent. This study showed that the use of contraceptives or family planning by female adolescents in the Kabuh District is a common practice. Female adolescents interpreted family planning practices as prevention of pregnancy. The most commonly used contraceptives are the contraceptive injection and the birth control pill. Adolescents obtained preference for contraceptives from their parents and family. Meanwhile, family planning services were only provided through a midwife using the One-Stop Service method. Cultural values and customs that are deeply rooted in the Manduro community make the practice of pre-marital family planning perpetuated, even though it contradicts information in general and religion. This study concluded that the practice of pre-marital family planning is believed to be the best solution for female adolescents who are engaged but still want to seek new experiences.
\end{abstract}

Keywords: contraception; female adolescents; rural; social construction

\begin{abstract}
Abstrak
Kontrasepsi merupakan suatu upaya yang digunakan untuk mencegah terjadinya kehamilan pada perempuan usia subur. Dewasa ini, kontrasepsi tidak hanya digunakan pada perempuan dewasa atau yang telah memiliki pasangan saja, namun juga pada remaja perempuan. Studi ini bertujuan untuk memahami praktik penggunaan kontrasepsi pada remaja perempuan di pedesaan. Teori yang digunakan sebagai pisau analisis adalah teori konstruksi sosial oleh Peter L Berger dan Thomas Luckmann. Studi ini menggunakan metode kualitatif. Subjek penelitian dalam studi ini adalah perempuan yang menggunakan alat kontrasepsi saat remaja. Studi ini menunjukkan bahwa penggunaan alat kontrasepsi atau KB oleh remaja perempuan di kecamatan Kabuh merupakan hal yang biasa dilakukan. Remaja perempuan memaknai praktik KB sebagai pencegahan terhadap kehamilan. Alat kontrasepsi yang paling sering digunakan adalah suntik KB dan pil KB. Preferensi tentang kontrasepsi didapat remaja dari orang tua dan keluarga, sementara itu pelayanan KB hanya melalui bidan dengan metode One Stop Service. Nilai budaya dan kebiasaan yang mengakar kuat dalam masyarakat Manduro membuat praktik KB pranikah tetap dilanggengkan, meskipun mengalami benturan dengan informasi secara umum dan agama. Studi ini menyimpulkan praktik KB sebelum menikah dipercaya sebagai solusi terbaik bagi remaja perempuan yang terikat dalam status pertunangan namun masih ingin mencari pengalaman baru.
\end{abstract}

Kata Kunci: kontrasepsi; remaja perempuan; pedesaan; konstruksi sosial

\section{Introduction}

Adolescence is a phase in human growth and development which is usually referred to as the transition period from children to adults with an age range of 10 to 19 years. There are three stages in the adolescent phase according to The Health Resources of Services Administration Guidelines, including early adolescence, middle adolescence, and late adolescence (Afrilia \& Cahyanti 2017). According to the 2020 population census, the number of female adolescents in Indonesia was more than 12 million, aged between 15 and 19 years. Female adolescents who married at that age were 17\% (BKKBN \& CNN Indonesia 2020). The majority of adolescents in developing countries do not complete their education, do 
not work, and are financially dependent on their parents. Another problem for adolescents in developing countries is the lack of stable mental formation that affects every decision they make (Rohmah et al. 2020).

Adolescence has a fairly high vulnerability to risky behavior such as premarital sex, so it does not rule out the possibility of unintended pregnancies to sexually transmitted diseases (Manlove \& Franzetta 2003). Data from the World Health Organization (WHO) show that adolescents in developing countries aged 15 to 19 years experience a pregnancy rate outside of the marriage of up to $49 \%$ every year (Planification Familiale 2016). Cases of unintended pregnancy are closely related to abortion. In Indonesia, the possibility of abortion cases is two million times in one year. This is strongly related to the high maternal mortality rate, which is 228 people for every one hundred thousand live births (Maridjan 2019).

A study on adolescents in Malawi showed that pregnant female adolescents in Sub-Saharan Africa indicated that their awareness of health risks was still low (Mekonnen et al. 2019). Moreover, female adolescents in the United States, which is a developed country, do not show a critical attitude to seek information about adolescent pregnancy (Fisher et al. 2019). Meanwhile, only a few female adolescents understand the dangers of contraception in Nigeria (Arisukwu et al. 2019). Mental and psychological immaturity of adolescents causes pregnant adolescents in South Africa to receive negative stigma from the surrounding environment, such as family, teachers, medical personnel, and friends of the same age (Amod et al. 2019). The immature physical condition of adolescents during pregnancy also causes some health problems such as anemia, underweight, premature birth, and high blood pressure (Zer et al. 2019).

Risky sexual behavior acted by adolescents that allows unintended pregnancies can now be prevented by carrying out a Family Planning (KB) program. The Family Planning Program or KB is a way to reduce maternal mortality, reduce the number of births, maintain birth spacing, and control maternal gestational age (Kemenkes RI 2012). Adolescents in Pamulang use contraceptives to prevent pregnancy. However, with the lack of knowledge, they need reproductive health counseling and sexual education (Afrilia \& Cahyanti 2017). Adolescents who use contraceptives are those who engage in promiscuity, which is more directed to western cultures such as cohabitation and free sex (Maulida 2016). The free sale of contraceptives, such as condoms, indirectly makes it easier for adolescents to have free sex. The main purpose of contraceptives is to prevent pregnancy, but the free sale has resulted in many adolescents abusing it (Dwi 2012).

Proper use of contraception, reproductive health, and general health are stated in the SDGs or Sustainable Development Goals. Goal number 3 in the SDGs specifically has important points to achieve, which are reducing maternal and infant mortality rates, controlling HIV/AIDS, and improving health services, particularly in the Family Planning program. One of the SDGs targets in number 3 is to reduce maternal mortality to less than 70 per 100,000 live births (BAPPENAS 2021). The 2018 Statistics Indonesia data showed that there were 257,216 couples of childbearing age in East Java Province with a percentage of $80 \%$ of contraceptive users. The 2019 National Population and Family Planning Board of East Java report showed that there was an increase in the use of modern contraceptives from 66.20 to 60.48 . Another reported target is the strengthening of PIK-R (Youth Information and Counseling Center) in reproductive health and nutrition education for adolescents, which has reached 100\% (BKKBN Jatim 2019).

The use of contraceptives is not only done by couples of childbearing age but also adolescents. The registration by the relevant institution only covers young married female adolescents but ignores the possibility of using contraception outside of marriage. Married adolescents between the ages of 1519 years in East Java who use the IUD are 1,5\%, the birth control pill is 7,2\%, and the method of coitus interruptus is $2,3 \%$ (Devi \& Sulistyo 2019). Adolescents use contraceptives to prevent unintended pregnancies. The age of adolescents who have not received too much information causes them to be unable to determine what is good and bad. 
The use of contraceptives in adolescents was viral in Pamekasan, Madura. The act of buying up condoms by students in Pamekasan was not a common act of buying, but also an early sign of free sex behavior. It aims to prevent pregnancy and protect them from sexually transmitted diseases. Meanwhile, sexual behavior is carried out on the basis of consensual and sexual needs, so that there are no objections between the two parties (Ariyani 2021). The use of contraceptives in adolescents has been considered normal, as a form of preventing pregnancy and avoiding sexually transmitted diseases. The most commonly known contraceptives are birth control pills and condoms. Adolescents who live in big cities are more aware of information about contraception than those who live in villages because access to information in urban areas is much more affordable. Adolescents in cities are more open-minded in studying sex education, but not with those in rural areas who still consider sex education as something taboo (Musafaah 2007).

Adolescents in Bali are also familiar with contraceptive methods. The most common of which are birth control pills and condoms. The majority of adolescents in Bali have experienced a courtship, where there are several activities that lead to sexual activity. Adolescents usually do petting, oral sex, or kissing, and these practices are considered normal. They do not allow sexual intercourse but 2,28\% of adolescents out of 526 respondents have had sexual intercourse (Listyowati et al. 2017). The use of contraceptives in adolescents occurs because of the instability of their social life, parental divorce, lack of affection from parents, and lack of moral and religious values. Technological developments and globalization developed along with adolescent desires that are difficult to control, especially in sexual behavior. The use of contraceptives, on the other hand, is a way to control the incidence of pregnancy outside of marriage and the transmission of sexually transmitted diseases (Saputra 2014).

Based on the problems that have been explained above, the use of contraceptives in adolescents is like an iceberg phenomenon because many cases are not revealed. The use of contraceptives is also influenced by the environment and from within each individual. The data presented by the government are data on the use of contraceptives in couples of childbearing age (PUS), but they neglect unmarried adolescents. The use of contraceptives indicates the presence of sexual activity in adolescents. As presented by previous data, that risky sex in adolescents will cause other problems such as unintended pregnancies, maternal and infant mortality, premature birth, and so on.

In Jombang Regency, cases of young marriage increased by 100\%. Public Relations of the Religious Court of Jombang Regency stated that the application for dispensation in 2020 reached 355 applications, compared to only 93 applications in 2019 (Dwi 2020). The reality in the field shows that marriage at a young age is common in Manduro Village. Efforts to reduce the number of young marriages have been carried out by the local government, such as socialization and counseling. Marriage at a young age is in line with the habit of using pre-marital contraceptives. Therefore, this study aimed to understand the reality of the use of contraceptives among adolescents in Manduro Village. Besides, this study also aimed to explain the factors that underlie adolescents in Manduro using contraceptives.

\section{Research Methods}

This study used a qualitative approach to obtain more detailed data. The results of this study are expected to be able to provide an explanation to the community about the reality of using contraceptives in adolescents, especially in rural areas. This study was conducted with a focus on adolescents who are currently or have used contraception, both before and after marriage. Rural areas in the Kabuh District, Jombang Regency, were chosen as the research site due to their location which is quite far from the city center, so that information and services about health are still far from adequate.

The data were collected according to the type of data, consisting of primary data and secondary data. The secondary data were obtained from the Statistics Indonesia of Jombang Regency, National Population and Family Planning Board of Jombang Regency, and the Kabuh District Government. Not only demographic data, but it also used other secondary data such as books, journals, research reports, etc. The primary data were obtained from in-depth interviews with various parties to explore in-depth information. 
Determination of research subjects and informants was carried out according to the criteria that have been made. First, the informant must be female. Second, the informant must have or are currently doing the pre-marital family planning program. Third, the informant must understand reproductive health and contraceptives. Based on these categories, the researchers obtained five subject informants and three non-subject informants, including SAL, SUS, KAR, RIN, DIN, TIT, ELA, SAI, and NAV. Besides subject informants as contraceptive users, there are also non-subject informants. The presence of nonsubject informants was intended to provide additional information and explanations about the research topic. In this case, the non-subject informants included the Village Head, Midwife, Community Health Center Personnel, and Health Cadres. The five subject informants are considered to be able to provide an in-depth and varied overview of the reality of pre-marital family planning through the additional information from non-subject informants. This study has looked for variations from subject informants to be able to represent the depth of the data.

Table 1 presents the informants' data which shows the profile of the informants in this study. In the subject informants, the education achieved is up to the senior high school level only, while in the nonsubject informants, there are informants who have completed their undergraduate program. The gap is due to differences in the role and social status of the informants.

Table 1.

Categorization of the informants

\begin{tabular}{|c|c|c|c|c|c|}
\hline No. & Name & Married age & Current age & Education & $\begin{array}{c}\text { Family } \\
\text { planning type }\end{array}$ \\
\hline 1 & SAL & 17 years & 22 years & $\begin{array}{l}\text { Senior High } \\
\text { School }\end{array}$ & Injection \\
\hline 2 & sus & 16 years & 20 years & $\begin{array}{l}\text { Junior High } \\
\text { School }\end{array}$ & Injection \\
\hline 3 & KAR & 17 years & 20 years & $\begin{array}{l}\text { Junior High } \\
\text { School }\end{array}$ & Injection \\
\hline 4 & RIN & 15 years & 18 years & $\begin{array}{l}\text { Junior High } \\
\text { School }\end{array}$ & Pill \\
\hline 5 & DIN & 16 years & 19 years & $\begin{array}{l}\text { Junior High } \\
\text { School }\end{array}$ & Pill \\
\hline 6 & TIT & 22 years & 32 years & Undergraduate & IUD \\
\hline 7 & ELA & 20 years & 22 years & $\begin{array}{l}\text { Senior High } \\
\text { School }\end{array}$ & Injection \\
\hline 8 & NAV & 19 years & 23 years & $\begin{array}{l}\text { Associate } \\
\text { Degree }\end{array}$ & Calendar \\
\hline 9 & SAI & 18 years & 45 years & $\begin{array}{l}\text { Senior High } \\
\text { School }\end{array}$ & IUD \\
\hline
\end{tabular}

After obtaining the primary and secondary data, the next step was conducting data analysis. The data were processed qualitatively by giving categories or grouping the data based on points that are in line with the research focus (Suyanto \& Sutinah 2007). The first thing to do is writing the transcript, categorizing the data, and interpreting the data based on the theory that had been chosen, which was the social construction theory proposed by Peter L Berger and Thomas Luckmann. The interpretation also discussed data findings and results from previous studies to compare and complete the data. The data processing was carried out to draw conclusions about the practice of using pre-marital contraceptives in adolescents, as well as to find out the factors that influence this behavior. This article was the final presentation of this study. 


\section{Results and Discussion}

\section{Information on contraception}

Contraception is a term that is linguistically a combination of the terms 'contra' and 'conception'. Contraception means to prevent or fight. Meanwhile, conception is a process of meeting between sperm and a mature egg which is then can cause pregnancy. Thus, contraception means an effort to prevent pregnancy as a result of the meeting of egg and sperm cells. Contraception itself is actually carried out by couples of childbearing age who are sexually active but do not or do not intend pregnancy (Suratun et al. 2008).

Table 2 describes the types of contraception commonly known by the general public. There are various types of contraceptives, both hormonal and non-hormonal. Several contraceptives that can be an option are as follows:

Table 2.

Type of contraceptives

\begin{tabular}{|c|c|c|}
\hline No. & $\begin{array}{c}\text { Type of } \\
\text { contraceptives }\end{array}$ & Definition \\
\hline 1 & Condom & $\begin{array}{l}\text { A rubber sheath made with various basic materials such as rubber, } \\
\text { animal essence, and plastic. Condoms are placed on the penis } \\
\text { during sexual intercourse. Besides functioning to prevent the } \\
\text { sperm from entering the uterus, condoms also function to prevent } \\
\text { the transmission of sexually transmitted diseases. }\end{array}$ \\
\hline 2 & Diaphragm & $\begin{array}{l}\text { A round cap that is convex and is inserted into the vagina before } \\
\text { sexual intercourse to close the cervix. The diaphragm helps block } \\
\text { the entry of sperm into the uterus. }\end{array}$ \\
\hline 3 & Spermicide & A substance that kills sperm, so they are unable to fertilize an egg. \\
\hline 4 & Birth Control Pill & $\begin{array}{l}\text { An ingredient consisting of artificial hormones to influence } \\
\text { hormones in women to suppress ovulation and thicken cervical } \\
\text { mucus. Hormones in birth control pills can be either progesterone } \\
\text { and estrogen or only progesterone. }\end{array}$ \\
\hline 5 & $\begin{array}{l}\text { Contraceptive } \\
\text { Injection }\end{array}$ & $\begin{array}{l}\text { Artificial hormones that are inserted into the body by injection. The } \\
\text { way it works is the same as birth control pills, so does the hormone } \\
\text { in it. }\end{array}$ \\
\hline 6 & Implant & $\begin{array}{l}\text { A contraceptive in the form of a rubber implant that contains } \\
\text { hormones and is implanted in the upper arm. The hormones will } \\
\text { be released every day to inhibit ovulation. }\end{array}$ \\
\hline 7 & IUD & $\begin{array}{l}\text { Abbreviation of Intra Uterine Devices. It can be in the form of } \\
\text { hormonal or regular contraceptives. The hormonal IUD is a copper } \\
\text { coil that is inserted into the vagina. }\end{array}$ \\
\hline 8 & Sterilization & The cutting or binding of sperm cell ducts. \\
\hline
\end{tabular}

Source: (Dwi 2012)

There are many types of contraceptive methods, both in the form of tools and those that contain hormones. Limited information makes the informants do not understand the types of contraception and the way to use them. The background of the informants, who generally have low education, becomes an obstacle in accessing information about contraceptives. Besides, the location of the informants' residence in rural areas also influences the extent of knowledge about it (Musafaah 2007). The contraceptive methods known by the informants are birth control pills and contraceptive injections.

Condoms, which are considered the easiest tool for adolescents to use (Maulida 2016), are in fact not used by adolescents in Kabuh District. Although the availability of condoms is easy to find in the market, female adolescents prefer injections as an alternative. Female adolescents also do not understand the risks of using contraceptives freely and the impact of premarital sex. Compared to adolescents in 
Switzerland who get knowledge about reproductive health and contraception during school and in their community, the adolescents in Indonesia do not get the knowledge (Ottesen et al. 2020). Information on reproductive health is considered a bit taboo and inappropriate to talk about in public (Irani \& Robab 2019). Adolescents in Kabuh District received socialization about reproductive health, but not with contraception. They got the information traditionally, particularly from parents or family.

\begin{abstract}
"The socialization that I conducted with the cadres was about reproductive health, as I said yesterday, usually at the integrated health services post (Posyandu) for adolescents or toddlers or official socialization (from the community health center). When it comes to contraception, we don't mention it in the socialization, unless the person comes for a consultation, I usually provide the information." (informant TIT)
\end{abstract}

Based on the explanation from the village midwife, information about contraception and family planning programs was not widely discussed in the socialization. The village midwife only provided private consultation. In addition, the family planning program was also socialized regarding the "two children is enough" campaign, without mentioning a number of types of contraception and how they work. The Guidelines for Integrated Reproductive Health Services at the Basic Health Service Level state that family planning services are carried out through a One-Stop Service system. In fact, counseling on contraception should be conducted at the community health center (Kemenkes RI 2015).

\title{
Experiences of female adolescents using contraceptives
}

Adolescents in Bali are familiar with contraceptives in general in the form of condoms and birth control pills (Listyowati et al. 2017), but not with female adolescents in Kabuh. Injections are better known and widely used in preventing pregnancy, both among adolescents and adult women in Kabuh. Table 3 shows the level of family planning participation among the community for each type of family planning in 2019. In Table 3 below, contraceptive injections and birth control pills are still the main choices for the Kabuh community.

Table 3.

Family planning participation by type of contraceptives

\begin{tabular}{lccccccccc}
\hline \multicolumn{1}{c}{ Village } & PUS & IUD & MOP & MOW & Implant & Injection & Pill & Condom & Total \\
\hline Marmoyo & 206 & 2 & 16 & 7 & 8 & 85 & 41 & 4 & 369 \\
Tanjung Wadung & 582 & 6 & 1 & 9 & 7 & 379 & 61 & 3 & 1,048 \\
Mangunan & 668 & 12 & 1 & 13 & 7 & 367 & 154 & 11 & 1,233 \\
Kedungjati & 742 & 61 & 5 & 32 & 14 & 385 & 130 & & 1,372 \\
Kabuh & 751 & 39 & 4 & 37 & 15 & 348 & 183 & 4 & 1,381 \\
Karang Pakis & 802 & 27 & 5 & 45 & 41 & 401 & 136 & 7 & 1,464 \\
Banjardowo & 597 & 44 & 1 & 37 & 34 & 276 & 89 & 5 & 1,083 \\
Sumber Ringin & 335 & 36 & 1 & 22 & 18 & 122 & 75 & 5 & 614 \\
Sumber Gondang & 375 & 24 & 3 & 14 & 40 & 176 & 58 & 2 & 692 \\
Kauman & 343 & 17 & 1 & 11 & 22 & 126 & 72 & 4 & 596 \\
Munung Kerep & 501 & 16 & 2 & 4 & 18 & 340 & 12 & 3 & 896 \\
Genengan Jasem & 466 & 12 & 4 & 22 & 20 & 299 & 38 & 3 & 864 \\
Manduro & 810 & 10 & 3 & 66 & 95 & 408 & 67 & 2 & 1,461 \\
Sukodadi & 533 & 6 & 1 & 9 & 8 & 352 & 70 & 4 & 983 \\
Pengampon & 566 & 63 & 1 & 11 & 2 & 322 & 93 & 3 & 1,061 \\
Sumberaji & 402 & 23 & 1 & 5 & 5 & 221 & 73 & 2 & 732 \\
Total & $\mathbf{8 . 6 7 9}$ & $\mathbf{3 9 8}$ & $\mathbf{5 0}$ & $\mathbf{3 4 4}$ & $\mathbf{3 5 4}$ & $\mathbf{4 . 6 0 7}$ & $\mathbf{1 . 3 5 2}$ & $\mathbf{6 5}$ & $\mathbf{1 5 . 8 4 9}$ \\
\hline
\end{tabular}


This statement is in accordance with Table 3 regarding family planning participation by type of contraceptives in Kabuh. The participation rate in contraceptive injection reached more than 50\% of participants from all participants in the Kabuh District. Besides contraceptive injections, another contraceptive commonly used by adolescents is the birth control pill. Birth control pills also have the second-highest participation rate after contraceptive injections with more than 1.000 participants.

Informants SAL, SUS, and KAR conducted pre-marital family planning programs using the contraceptive injection method. This method was also continued when they had children. SAL and SUS used the contraceptive injection after they were engaged with their partners.

\footnotetext{
"Yes, Miss, I follow the family planning program. Indeed, after the engagement, the couple will usually be asked to follow the family planning program here, Miss. After the engagement, I take the family planning program, the contraceptive injection given by the midwife. That's because my mother told me to do it, so I'm just going to do it. I'll be ashamed if there anything unwanted happens, Miss." (informant SAL)
}

Pre-marital family planning which is carried out after the engagement procession is common in this community. Informants SAL and SUS said that they administered routine contraceptive injections once a month to the local village midwife. Informant KAR also did the contraceptive injection after the engagement with her future husband. The difference is that, while informants SUS and SAL get married through the courtship process, informant KAR goes through the matchmaking process.

It is different with informants DIN and ELA who use birth control pills as a way to prevent pregnancy. However, the time they took the birth control pill was the same as the previous informants, which was after the engagement. This is in line with the results of a study (Tayo et al. 2011) which showed that the birth control pill is one of the most preferred contraceptive methods for its convenience and lots of information available from the surroundings.

Informant TIT as a midwife also said that she provides services to many female adolescents who have routinely carried out contraceptive injection programs. TIT usually recommends an injection program once a month, with the aim of maintaining the adolescents' menstrual period. SAI and NAV also admit that pre-marital family planning has become commonplace in Manduro. All informants in this study realized that the use of contraceptives among female adolescents should not be carried out because it is the same as legalizing free sex. However, this is in conflict with the customs, culture, or values that are believed by the local community that it is better to do family planning to prevent unwanted things to happen.

In line with this reality, Berger stated that there are two kinds of reality that exist in society to understand knowledge, including objective reality and subjective reality. Berger argued that the reality that exists in everyday life is a series of various typifications (Berger \& Luckmann 1990). The reality shows that, in the externalization phase, there is socialization to women in Kabuh District about contraception. Socialization is carried out by families, schools, peers, to the government and health institutions (Sa'adah 2019). Next, in the objectivation phase, there is the dialectical process between information and the reality that female adolescents have used to use contraceptives before marriage. This makes female adolescents doubt the objective reality that has been accepted. Lastly, it comes to the internalization phase where female adolescents interpret pre-marital contraception as a natural thing to do, especially by those who have been engaged.

\section{Reasons for adolescents to use contraceptives}

The use of contraceptives by adolescents is certainly not decided by themselves, but there are other parties who influence it. According to Magnusson et al. (2012), a more mature adolescent age allows them to be able to better plan about the family planning program, while young adolescents will have difficulties due to limited information and access. This is different from the data in the field which 
indicated that all engaged adolescents will do family planning, regardless of age. Family planning preferences for adolescents in Manduro are suggested by their families, especially mothers. Informants SAL, SUS, DIN, and RIN received advice from their mothers to carry out a family planning program after getting engaged to their future husbands. This was confirmed by the village midwife as follows:

"I think they understand it, Miss.s a proof, the girls are asked to the pre-marital family planning. It was their parents who ordered them to do so, but surely their parents would give them understanding to their daughters why they had to do family planning. From that point, I conclude it myself, Miss, because I don't dare to ask them, hehe." (informant TIT)

Mothers play an important role in making decisions for their daughters whether to carry out family planning programs or not. KAR did not get advice from her mother to do family planning, but from her older sister. As understood by adolescents in Manduro, family planning programs are carried out to prevent pregnancy (Musafaah 2007). They do not know other functions, such as preventing the transmission of sexually transmitted diseases when using condoms. Female adolescents in Manduro carry out a family planning program to prevent pregnancy, which is a recommendation from the family of the female adolescents.

Adolescents' desire to enjoy their youth but are bound by an engagement relationship makes them look for solutions by means of family planning. KAR and SUS said that they still want to enjoy their youth without having to worry about getting pregnant before marriage and the hassle of having to take care of children at a young age. Moreover, the habits and values of the Manduro community regarding pre-marital family planning have become a reference for female adolescents. Even though it is known that pre-marital family planning is the same as allowing pre-marital sex, but for reasons of avoiding the risk of pregnancy, this practice is increasingly perpetuated. This decision is the result of a dialectic process in the objectivation phase. The objectivation phase is a phase where there is a conflict between the individual's objective and subjective reality (Berger \& Luckmann 1990). The information that contraception can only be used by married women clashes with the habits of female adolescents in the Kabuh District. The subjective reality which has indirectly become a habit and is trusted by the community is able to dominate the thinking of female adolescents to use pre-marital contraception.

\section{Dialectic of the construction process of pre-marital family planning}

According to Berger and Luckmann, reality can be created because of a dialectical process. Individuals create a reality with an externalization process which is then influenced in the objectivation process to the internalization process. Individuals will be able to digest situations and circumstances in everyday reality through these three phases. The process of forming social reality will go through three phases, including externalization, objectivation, and internalization (Berger \& Luckmann 1990). Externalization is the phase carried out by the individual in adapting and recognizing a particular object. Objectivation is the phase of interaction between the individual and their intersubjective world. Internalization is the phase of determining decisions and individual behavior to conclude the truth about something.

In the externalization phase, female adolescents in Kabuh received information about contraceptives and family planning programs. The information was conveyed by the family, especially the girls' family and also their friends of the same age. There was no formal socialization about the concept of contraceptives in adolescents. In this phase, they know that pre-marital family planning is a common thing for female adolescents in Manduro. From their mother or older sister, adolescents know that family planning is used to prevent pregnancy. The most commonly known information about family planning programs is contraceptive injection and birth control pills.

In the objectivation phase, it shows that there is a debate between information on contraceptive use and individual values or beliefs. In this case, all informants understood that the use of contraceptives indicates sexual activity in unmarried adolescents. Pre-marital sex is prohibited in some religions and can cause 
harm to the perpetrator. However, it is undeniable that the habits and beliefs of the local community indicated that female adolescents who are engaged usually carry out family planning programs. Premarital family planning which is considered right by the local community then creates habitualization which will eventually form institutionalization.

Meanwhile, in the internalization phase, female adolescents interpret the meaning of pre-marital contraception. They understand contraception as an effort to prevent pregnancy, which is what adolescents in Manduro usually do. Despite knowing that pre-marital sex and family planning for adolescents should not be carried out, the existing beliefs and habits of pre-marital family planning function as guidelines for the lives of female adolescents in Manduro. This meaning will continue to experience dynamics, especially when new information or issues emerge in the life of the Manduro community.

\section{Conclusion}

The use of contraceptives and family planning programs is a reality that is considered right by female adolescents in Manduro. Several types of contraceptives that are often used are contraceptive injection and birth control pills. This is explained in the table on the use of contraceptives in Kabuh which shows the high use of contraceptive injections and birth control pills. The female adolescents in Manduro understand contraception only as a means to prevent pregnancy, without knowing about its other functions or side effects. Information about family planning programs is not conveyed openly to the community and adolescents, but through personal services with village midwives or called One-Stop Service. The preference of female adolescents in Manduro in determining the contraceptive method to be used is obtained from the family, especially the mother and sister. The use of pre-marital contraceptives is considered a natural thing and is commonly carried out by female adolescents in Manduro. It aims to prevent pregnancy in those who are still at a young age and still have many activities to do. Pre-marital family planning is also carried out because of the culture of the Manduro community, in which when female adolescents have done the engagement, they are recommended to take part in the family planning program.

This study differs from previous research because the cultural aspect is more emphasized. In previous studies, the use of pre-marital contraception was done because of free sex. Meanwhile, this study highlighted the use of pre-marital contraception regarding the belief of the local community. The use of pre-marital contraceptives is believed to be able to prevent the possibility that hinders the development of female adolescents, especially in careers. Another novelty was also shown that the use of pre-marital contraception was carried out after the engagement to prevent pre-marital pregnancy. This study concluded that pre-marital family planning is a common and entrenched reality in the Kabuh community. The information has been provided by the relevant parties, but it clashes with the values and beliefs of the Kabuh community.

\section{References}

Afrilia EM \& Cahyanti YD (2017) Hubungan sikap remaja dengan penggunaan kontrasepsi pada anak jalanan. JKFT 2: 8-13.

Amod Z, Halana V, \& Smith N (2019) School going teenage mothers in an under-resourced community: Lived experiences and perceptions of support. Journal of Youth Studies 22 (9):55-71.

Arisukwu O, Igbolekwu O, Efugha I, Nwogu J, Osueke N, \& Oyeyipo E (2019) Knowledge and perception of emergency contraceptives among adolescents girls in Imo State, Nigeria. Sexuality \& Culture 24: 273-290.

Ariyani Y (2021) Aksi borong kondom pada pelajar di Kabupaten Pamekasan, Madura. Masyarakat, Kebudayaan dan Politik 21 (2):181-186.

BAPPENAS (2021) 3. Kehidupan sehat dan sejahtera. [Accessed 21 July 2021]. https://sdgs.bappenas. go.id/tujuan-3. 
Berger PL \& Luckmann T (1990) Tafsir Sosial Atas Kenyataan: Risalah tentang Sosiologi Pengetahuan. Jakarta: LP3ES.

BKKBN \& CNN Indonesia (2020) BKKBN nilai pernikahan dini sebagai bencana nasional. [Accessed 09 August 2021]. https://www.cnnindonesia.com/gaya-hidup/20200703183717-289-520695/ bkkbn-nilai-pernikahan-dini-sebagai-bencana-nasional.

BKKBN Jatim (2019) Lakip Perwakilan BKKBN Provinsi Jawa Timur. Surabaya: BKKBN.

BPS Kabupaten Jombang (2019) Kecamatan Kabuh Dalam Angka. Jombang: BPS.

Devi RA \& Sulistyo R (2019) Gambaran kepesertaan keluarga berencana di Provinsi Jawa Timur tahun 2018. Media Gizi Kesmas 8 (2):1-9.

Dwi A (2012) Memilih Alat Kontrasepsi Alami dan Halal. Solo: Aqwamedika.

Dwi A (2020) Tahun 2020, jumlah pernikahan dini melonjak 100 persen. Kabarjombang.com, 17 November. [Accessed 21 July 2021]. https://kabarjombang.com/peristiwa/tahun-2020-jumlahpernikahan-dini-di-jombang-melonjak-100-persen/.

Fisher C, Kerr L, Ezer P, Kneip P, Coleman J, \& Tibbits M(2019) Adolescents perspectives on addressing teenage pregnancy and sexually transmitted infection in the classroom and beyond. Sex Education 20 (1):90-100.

Irani M \& Robab LR (2019) Reproductive and sexual health consequences of child marriage: A review of literature. Journal of Midwifery and Reproductive Health 7 (1):1491-1497.

Kemenkes RI (2012) Pedoman Sistem Pencatatan dan Pelaporan Pelayanan Keluarga Berencana. Jakarta: Kemenkes.

Kemenkes RI (2015) Buku Pedoman Pelayanan Kesehatan Reproduksi Terpadu di Tingkat Pelayanan Kesehatan Dasar. Jakarta: Direktorat Bina Kesehatan Ibu.

Listyowati R, Nopiyani N, \& Indrayathi P (2017) Perception of contraception access and utilization in teenagers in Senior High School No 8 Denpasar, Bali. Journal of Health Science and Medicine 1 (2):27-30.

Magnusson B, Masho S, \& Lapane KL (2012) Early age at first intercourse and subsequent gaps in contraceptive use. Journal of Women's Health 21 (1):73-79.

Manlove JR \& Franzetta K (2003) Pattern of contraceptive use within teenagers first sexual relationship. Perspective on Sexual and Reproductive Health 35 (6):246-255.

Maridjan GN (2019) Aborsi dalam penerapan hukum pidana di Indonesia. Lex Crimen 8 (6):114-121.

Maulida A (2016) Fenomena Penyalahgunaan Alat Kontrasepsi. Thesis, Universitas Islam Negeri Ar Raniry, Banda Aceh.

Mekonnen T, Dune T, \& Pers J (2019) Maternal health service utilization of adolescent woman in Sub Saharan Africa: A systematic scoping review. BMC Pregnancy Childbirth 19: 1-16.

Musafaah M (2007) Pengetahuan dan sikap pemakaian kontrasepsi pada remaja putri gaul di Parkir Timur Senayan, Jakarta. Jurnal Kesehatan Masyarakat Nasional 22 (2):91-96.

Ottesen S, Narring F, Renteria S, \& Michaud PA (2020) Emergency contraception among teenagers in Swizterland: A cross sectional survey on the sexuality of 16 to 20 years old. Journal of Adolescent Health 31 (1):101-110.

Planification Familiale (2016) WHO releases new fact sheets on adolescent contraceptive use. [Accessed 09 August 2021]. https://partenariatouaga.org/en/releases-new-fact-sheets-adolescentcontraceptive-use/.

Rohmah N, Yusuf A, Hargono R, Laksono AD, Masruroh, Ibrahim I, \& Walid S (2020) Determinants of teenage pregnancy in Indonesia. Indian Journal of Forensic Medicine \& Toxicology 14 (3):21052110.

Sa'adah SF (2019) Pengambilan keputusan suami istri dalam menentukan pendidikan anak: Studi pada Muslimat Hidayatullah Surabaya. Jurnal Sosiologi Dialektika 14 (2):111-119.

Saputra H (2014) Persepsi remaja terhadap hubungan interpersonal laki-laki dan perempuan: Studi di Kecamatan Manggeng Kabupaten Aceh Barat Daya. Thesis, Universitas Islam Negeri Ar Raniry, Banda Aceh.

Suratun S, Tien H, \& Rusmiati S (2008) Pelayanan Keluarga Berencana dan Pelayanan Kontrasepsi. Jakarta: Trans Info Media. 
Suyanto B \& Sutinah (2007) Metode Penelitian Sosial Berbagai Alternatif Pendekatan. Jakarta: Prenadamedia Group.

Tayo A, Akinola O, Babatunde A, Adewunmi O, \& Shittu L (2011) Contraceptive knowledge and usage amongst female secondary school students in Lagos, Southwest Nigeria. Journal of Public Health and Epidemiology 3 (1):34-37.

Zer S, Wainstok T, Walfish A, \& Sheiner E (2019) Perinatal outcomes and long-term health in offspring of teenage mothers. Journal Pediatri Adolescent Gynecol 32 (6):1-22. 